\title{
Conjunctival Squamous Cell Carcinoma with Corneal Stromal Invasion in Presumed Pterygia: A Case Series
}

\author{
Pia R. Mendoza ${ }^{a}$ Caroline M. Craven ${ }^{b}$ Matthew H. Ip ${ }^{d}$ Matthew W. Wilson ${ }^{c}$ \\ Minas T. Coroneo ${ }^{d}$ Hans E. Grossniklausa, b \\ Departments of a Pathology and Laboratory Medicine and ${ }^{\mathrm{b}}$ Ophthalmology, Emory University, Atlanta, GA, and \\ 'Department of Ophthalmology, University of Tennessee Health Science Center, Memphis, TN, USA; ${ }^{d}$ Department \\ of Ophthalmology, University of New South Wales at Prince of Wales Hospital, Sydney, NSW, Australia
}

\section{Keywords \\ Conjunctiva - Cornea Squamous cell carcinoma . \\ Pterygium · Ocular surface squamous neoplasia}

\begin{abstract}
Aim: To describe 4 cases of conjunctival squamous cell carcinoma (SCC) with corneal stromal invasion. Methods: Retrospective, clinicopathologic case series. Results: All patients had prior resections of presumed pterygia. The degree of corneal involvement dictated the extent of surgical management. One eye with localized invasion was treated with lamellar keratoplasty and plaque brachytherapy. Another case with widespread invasion warranted penetrating keratoplasty and eventual enucleation. Two cases were treated medically prior to surgical intervention: one with localized invasion was treated with topical interferon and retinoic acid; another with significant inflammation was treated with doxycycline and fluorometholone. The patient who underwent keratoplasty and brachytherapy had no recurrence after 7 years of follow-up. Those initially treated medically had resections of recurrence but ultimately required enucle-
\end{abstract}

\section{KARGER}

(c) 2018 S. Karger AG, Basel

E-Mail karger@karger.com

www.karger.com/oop ation. Histologically, specimens demonstrated SCC invading the deep corneal stroma, with 2 tumors of the mucoepidermoid type. Conclusions: This series demonstrates the importance of maintaining clinical suspicion of conjunctival squamous neoplasia in pterygia. We recommend that all excised pterygia be submitted for histopathologic evaluation and be carefully evaluated for dysplasia and variants of SCC associated with increased risk of intraocular invasion. Undetected ocular surface squamous neoplasia may give rise to potentially vision- and eye-threatening invasive corneal SCC.

(c) 2018 S. Karger AG, Basel

\section{Introduction}

Pterygium is a common benign ocular surface disorder, characterized by centripetal growth of a leading edge of altered limbal epithelial cells followed by a body of squamous metaplastic epithelium with goblet cell hyperplasia and underlying stroma characterized by inflammation, activated fibroblasts, neovascularization, and extracellular matrix remodeling [1]. Its prevalence ranges from
Pia R. Mendoza, MD

1365 Clifton Rd NE BT428

Atlanta, GA 30322 (USA)

E-Mail pia.mendoza@emory.edu 
0 to $56 \%$ depending on geographical location [2], with higher rates observable in countries either close to the equator or with high terrain reflectivity [3] associated with greater exposure to ultraviolet (UV) light. Ocular surface squamous neoplasia (OSSN) encompasses a broad spectrum of neoplastic squamous abnormalities of the conjunctival, limbal and corneal epithelium. This spectrum ranges from benign behaving noninvasive squamous dysplasia or intraepithelial neoplasia to in situ and invasive squamous cell carcinoma (SCC) cases. Although the reported incidence rate ranges from 0.1 to 1.9 per 100,000 persons [4-6], OSSN remains the most common ocular surface tumor and conjunctival SCC is the most common ocular malignancy $[7,8]$. Conjunctival SCC has the potential to locally invade as well as metastasize, with a few case series [9-12] and case reports [1316] identifying intracorneal, intraocular and orbital invasion [17] by conjunctival SCC.

Pterygium and OSSN share common risk factors such as exposure to UVB light, and chronic ocular surface inflammation, although human papillomavirus infection appears to play a minor role in OSSN but not in pterygium pathogenesis [18]. Pterygium and OSSN lesions also present similarly as fleshy overgrowths typically at the limbus arising from the interpalpebral fissure. Furthermore, pterygium and OSSN can coexist, and several studies have implicated pterygium's origin as a stem cell disorder with premalignant features [19]. The rate of OSSN presence in excised pterygia specimens has been studied in several different countries with results ranging from 0 to $9.8 \%$ [20-23]. The presence of an unexpected OSSN with pterygium is a dilemma because of the vastly contrasting management procedures for pterygium and OSSN. OSSN is typically excised utilizing a no-touch technique with 2- to 4-mm margins, alcohol epitheliectomy to the cornea and adjuvant surgical margin cryotherapy $[12,24]$. The importance of achieving tumor-free surgical margins in excised OSSN is profound, with a recurrence rate of $56 \%$ in excised tumors with positive margins compared to $33 \%$ for excised lesions with tumor-free margins [25]. Topical interferon alfa-2b [26] and its combination with topical retinoic acid [27] are effective alternatives when treating OSSN. Pterygia, on the other hand, are conservatively managed with the use of UV protective eyewear and lubricants if with symptoms of ocular irritation. Surgical excision is indicated when there is visually significant induced astigmatism, threat of involvement of the visual axis, severe symptoms of irritation, and for cosmesis. Most surgeons prefer simple surgical excision, with or without intraoperative mitomycin $\mathrm{C}$ application.
The use of mitomycin $\mathrm{C}$ is helpful in reducing recurrence of pterygia and in the treatment of undetected OSSN [22].

Herein, we present the authors' experience with 4 patients who underwent excision for presumed pterygia and were subsequently found to have OSSN, and who developed deep corneal stromal invasion by conjunctival SCC. Clinical and pathologic features and management recommendations are discussed.

\section{Methods}

A retrospective review of medical records and pathology slides was conducted for 4 patients who underwent excision of a presumed pterygium with development of conjunctival SCC with corneal invasion. Patient records were reviewed for demographic data, clinical history, clinical findings, histopathologic findings, treatment methods, recurrence, and duration of follow-up. This study was approved by the institutional review board of Emory University, United States and the South Eastern Sydney Area Health Service Human Research Ethics Committee Northern Section (15/200), Australia.

\section{Results}

\section{Patient 1}

A 47-year-old female with keratoconus underwent excisional biopsy of a presumed pterygium in the right nasal limbus. Initial histopathologic evaluation revealed conjunctival intraepithelial neoplasia, grade 1 . The patient was lost to follow-up and no treatment was provided until 18 months later when she presented with blurring of vision and photophobia. The nasal limbal lesion had recurred with prominent neovascularization and adjacent corneal opacification. This lesion was rebiopsied revealing a diagnosis of intraepithelial neoplasia with areas suspicious for invasive SCC (Fig. 1). The patient was subsequently administered a topical combination of interferon alfa- $2 \mathrm{~b}$ and retinoic acid. After 2 weeks of topical therapy, the patient experienced irritation and was prescribed fluorometholone (FML) drops. Although the patient's visual acuity improved with clinically observable tumor regression after 7 months, the patient developed a focal region of corneal melt. Interferon alfa- $2 \mathrm{~b}$ and retinoic acid drops were discontinued and oral doxycycline and FML drops were initiated. The focal region of corneal melt stabilized and her ocular surface inflammation settled after 5 months although her right eye's visual acuity deteriorated further to count fingers. This right limbal lesion was rebiopsied, revealing a diagnosis of SCC, and was excised 


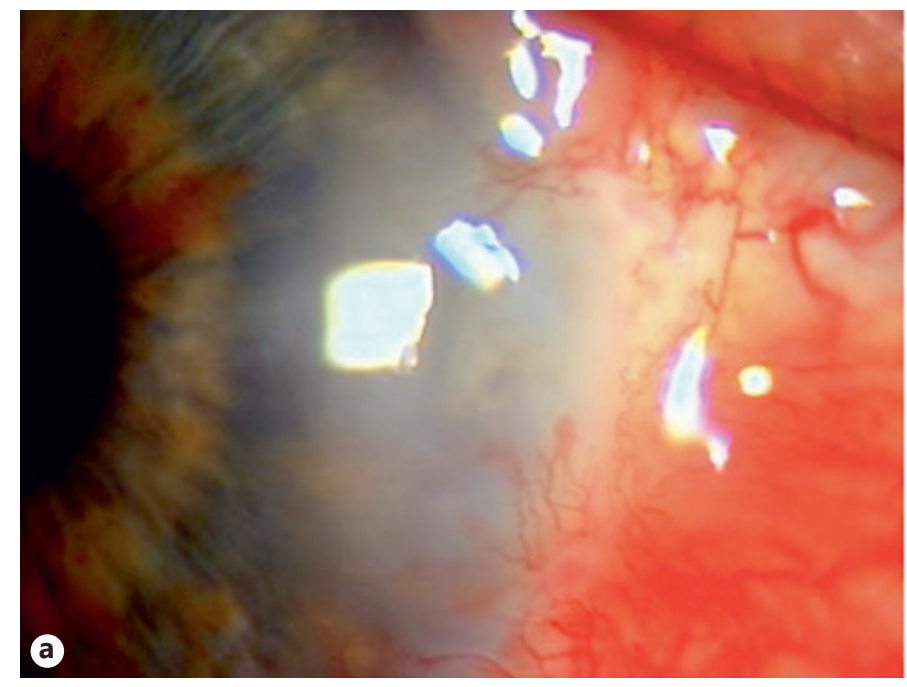

Fig. 1. Patient 1: a 47-year-old female underwent excisional biopsy of a presumed pterygium in the right nasal limbus, with initial histopathologic evaluation revealing conjunctival intraepithelial neoplasia. a Eighteeen months later, she presented with recurrence

completely with lamellar graft placement onto the excision site, with no immediate complications. No recurrence of the tumor was reported until 7 months postoperatively when she developed right ocular surface discomfort with worsening photophobia. Clinical examination revealed regions of inflammation involving the lamellar corneal graft. She was commenced on prednisolone drops and a rebiopsy was performed of this suspicious lesion, reconfirming a diagnosis of SCC of her right eye. Consequently, the patient underwent uncomplicated right eye enucleation. Histopathologic evaluation of the enucleated eye reconfirmed invasive SCC with involvement of the medial fornix within the cornea, bulbar conjunctiva and sclera, with tumor-free surgical margins. There was no local recurrence or metastasis after 5 years of follow-up.

\section{Patient 2}

A 61-year-old male underwent simple excision of a presumed pterygium in the right nasal limbus. Initial histopathologic evaluation was consistent with pterygium showing focal low-grade dysplasia and scattered goblet cells. No treatment was provided. Twelve months later, the patient presented with blurring of vision and an inflamed and vascularized right nasal limbal lesion was observed, along with basal corneal opacification involving the visual axis. The patient's eye was treated with oral doxycycline and FML drops for 8 months. At that time,

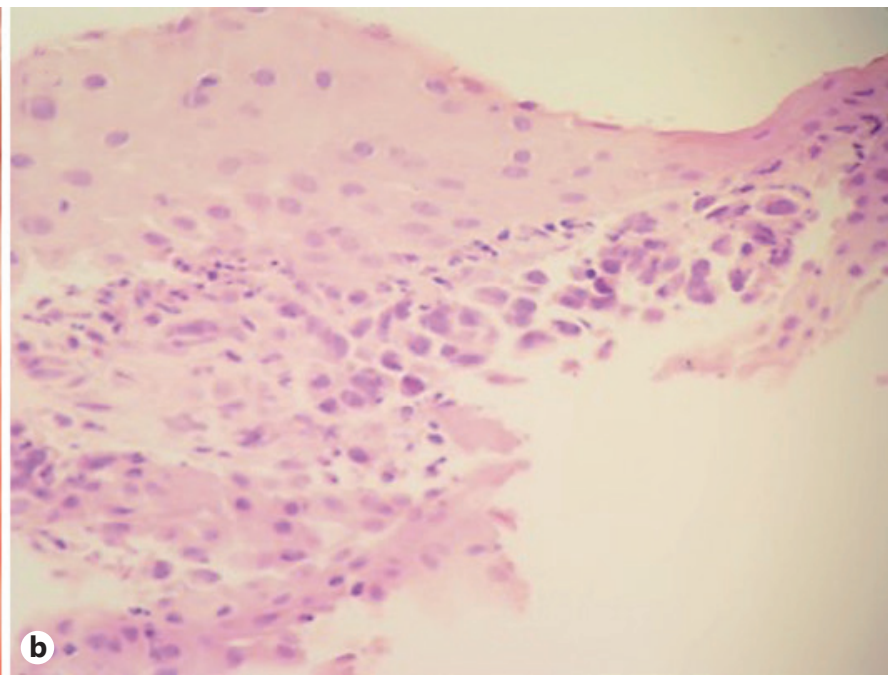

with prominent neovascularization and adjacent corneal opacification. b Rebiopsy showed intraepithelial neoplasia with areas suspicious for invasive SCC. HE. $\times 40$.

it was suspected that the presentation's cause was related to leakage of blood vessels in the original pterygium bed. Mild improvement in visual acuity and corneal haze clearing was achieved; however, a raised inflamed nodular area developed at the patient's superonasal limbus. The recurrent lesion was biopsied, revealing a diagnosis of invasive carcinoma. An anterior segment optical coherence tomography (OCT) scan suggested that the lesion remained within the confines of the globe. Followup CT and MRI investigations revealed no metastatic spread. Topical and intralesional interferon alfa-2b was applied for 3 months with no effect. Consequently, the patient underwent an uncomplicated right eye enucleation to remove the tumor and histopathologic analysis revealed mucoepidermoid (adenosquamous) SCC involving the nasal limbal cornea and sclera with intraocular extension, but with clear surgical margins (Fig. 2). There was no local recurrence or metastasis after 6 years of follow-up.

\section{Patient 3}

A 65-year-old male underwent simple excision of a presumed pterygium in the left temporal limbus. Histologic evaluation revealed a mucoepidermoid carcinoma. The patient was lost to follow-up until 24 months later when he presented with a dense inferotemporal corneal opacity with vascularization. There was no evidence of a recurrent limbal lesion. The opacity did not extend to the 

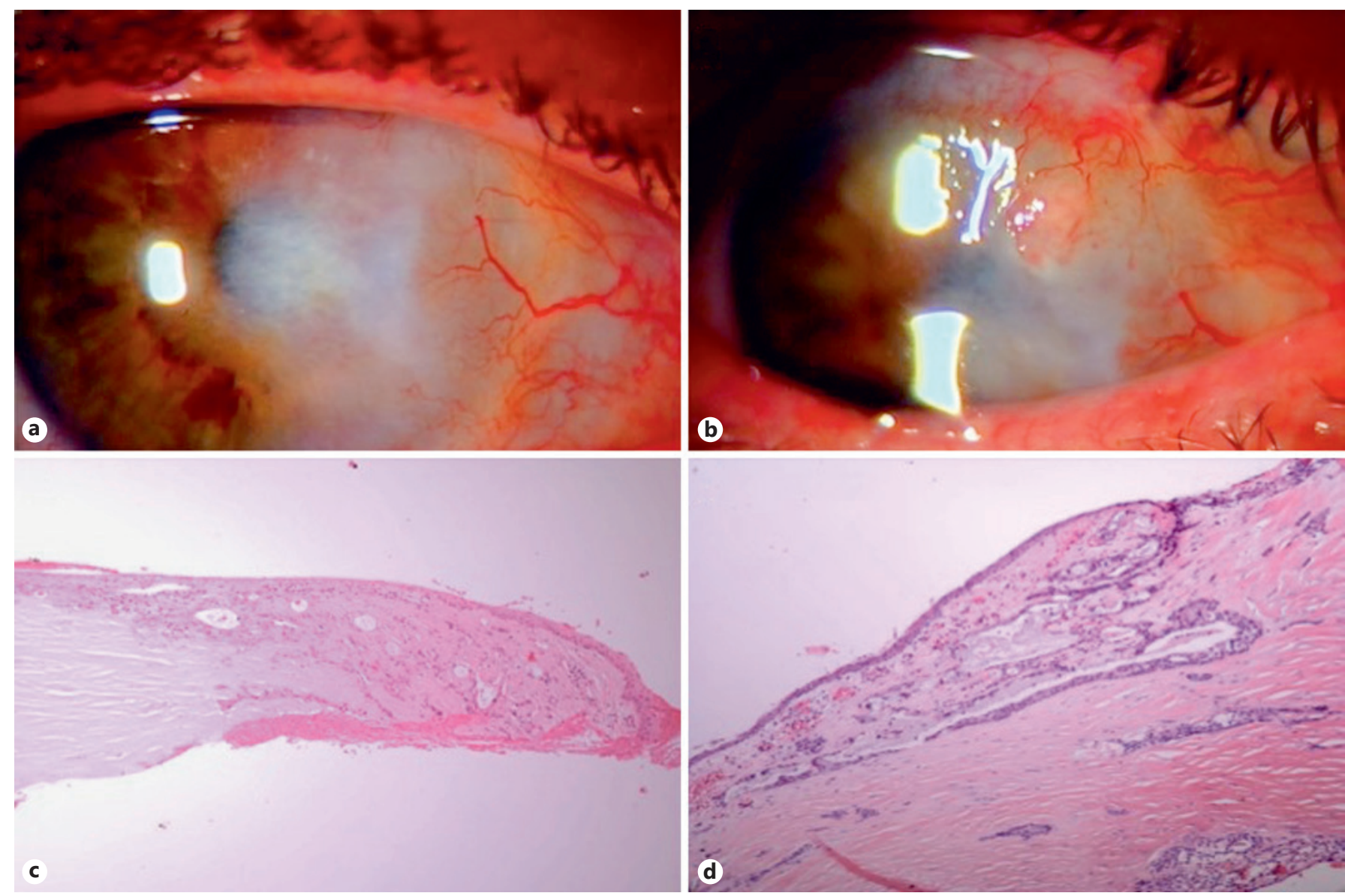

Fig. 2. Patient 2. a A 61-year-old male presented 12 months after simple excision of a presumed pterygium with inflammation, vascularization, and corneal haze in the right nasal limbal area. The patient was treated with oral doxycycline and FML drops for 8 months. b Subsequently, an inflamed nodule developed at the su-

visual axis. A corneal biopsy revealed recurrent mucoepidermoid carcinoma. The patient was treated with lamellar keratoplasty with peritomy and brachytherapy with a iodine-125 radioactive plaque. A corneal biopsy was taken at the time and the specimen confirmed recurrent mucoepidermoid carcinoma with deep corneal stromal invasion (Fig. 3). Surgical margins were clear of tumor. The graft remained stable and there was no local recurrence or metastasis after 7 years of follow-up.

\section{Patient 4}

A 75-year-old male underwent simple excision of a presumed pterygium in the right temporal limbus. The excised lesion was not submitted for histologic evaluation. Twelve months later, the patient presented with

blurring of vision and a nonhealing corneal defect. The limbal lesion recurred with an adjacent corneal defect and corneal opacification involving the visual axis. Anterior segment OCT showed thickening of the cornea. A corneal biopsy revealed invasive SCC. Resection of the limbal mass, eccentric penetrating keratoplasty, deep tenonectomy, and a $10-\mathrm{mm}$ resection of the lateral rectus muscle were performed. Specimens submitted for histopathologic evaluation showed all margins positive for invasive SCC with invasion into the deep corneal stroma abutting the Descemet membrane and residual tumor in the donor-host interface. The patient underwent right eye enucleation soon thereafter due to positive margins. Histopathologic evaluation of the enucleated eye revealed SCC arising from the conjunctival limbal epithelium and in- 

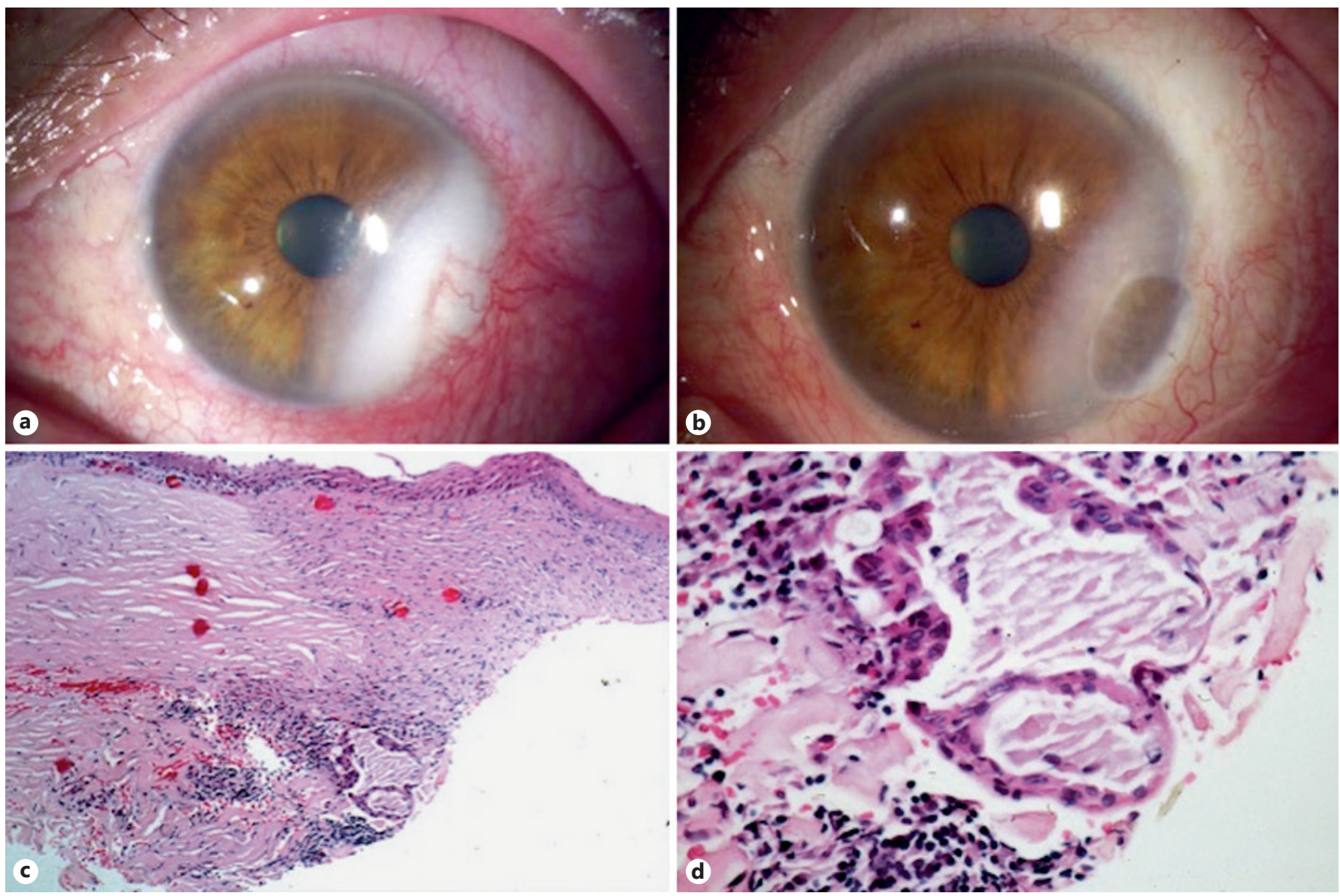

Fig. 3. Patient 3. a A 65-year-old male presented 24 months after simple excision of a presumed pterygium with an inferotemporal corneal opacity with vascularization not involving the visual axis. b The patient underwent lamellar keratoplasty and plaque brachytherapy. c Histopathologic evaluation of a corneal biopsy taken

during surgery revealed a corneal-limbal scar with a fibrovascular pannus. $\mathbf{d}$ There were islands of atypical squamous cells with abundant mucin, consistent with recurrent mucoepidermoid carcinoma. HE. $\times 4$ (c). HE. $\times 40$ (d).

vading to the level of the deep corneal stroma extending to the opposite limbal end (Fig. 4). Surgical margins were clear of tumor. There was no local recurrence or metastasis after 2 years of follow-up.

A summary of the 4 patients is shown in Table 1. The mean age at the time of excision of presumed pterygium was 62 years (range 47-75). There were 3 males and 1 female. All patients were Caucasian. None of the patients were infected with the human immunodeficiency virus (HIV) or immunocompromised. Two patients were from Australia and 2 were from the United States. All of the original lesions were located in the interpalpebral conjunctiva at the limbus, 2 on the nasal and 2 on the temporal side. All patients were managed initially with surgical excision of their original lesion for presumed pterygium.

One excised original lesion was not submitted for histopathologic evaluation. For the other 3 original lesions with histology, one showed conjunctival intraepithelial neoplasia grade 1, another showed pterygium with focal dysplasia, and the other showed mucoepidermoid SCC. The mean interval between the first tumor excision and the corneal invasion presenting as a corneal opacity was 16.5 months (range 12-24). Two cases were treated medically prior to surgical intervention, with limited tumor control, multiple recurrences, eventual intraocular invasion, and subsequent enucleation. One case with limited corneal invasion was successfully managed with surgery (lamellar keratoplasty combined with plaque brachytherapy). A case with an invasive recurrent lesion and extensive limbus-to-limbus corneal involvement was initially 

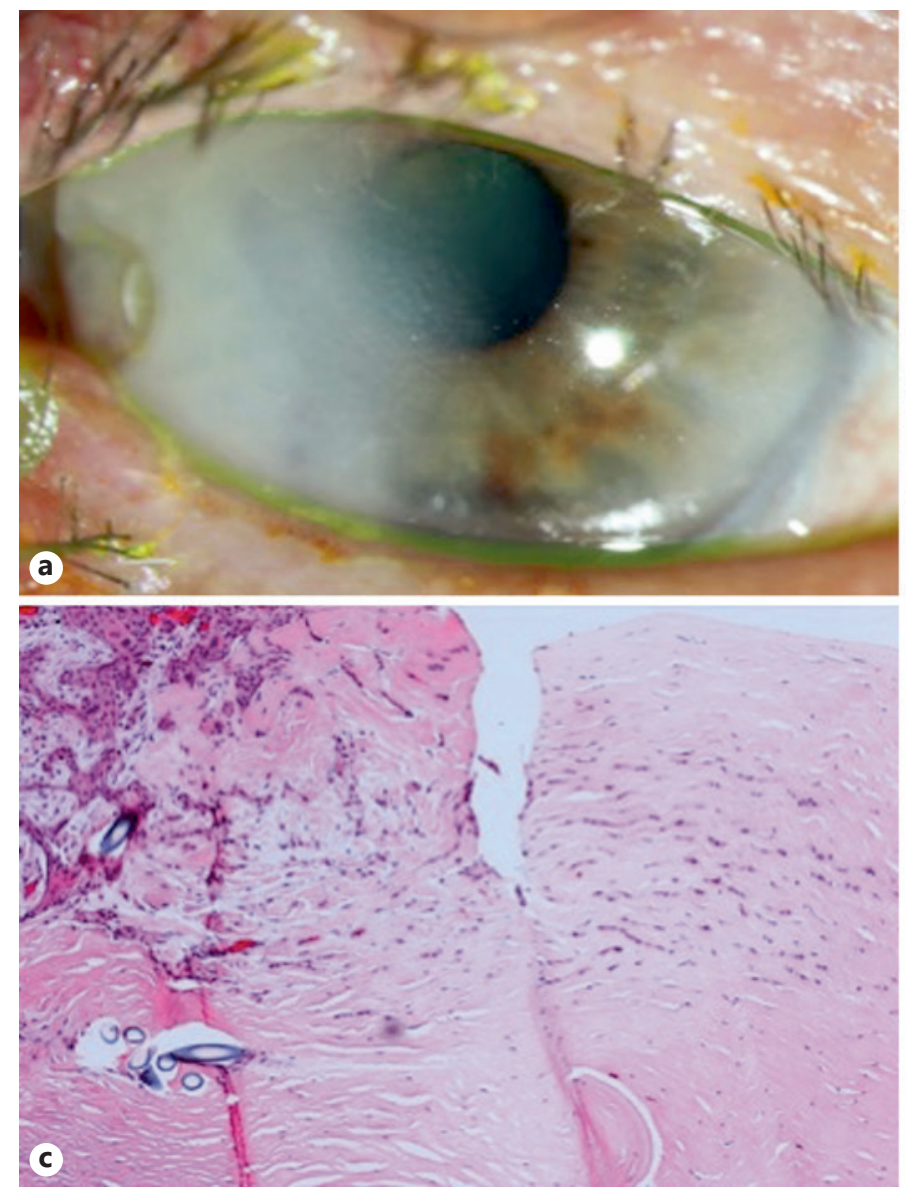

Fig. 4. Patient 4. a A 75-year-old male presented 12 months after simple excision of a presumed pterygium with a recurrent lesion, adjacent nonhealing corneal defect, and corneal opacification in the right temporal limbus. b Anterior segment OCT showed thickening of the cornea. c After corneal biopsy and eccentric penetrat-
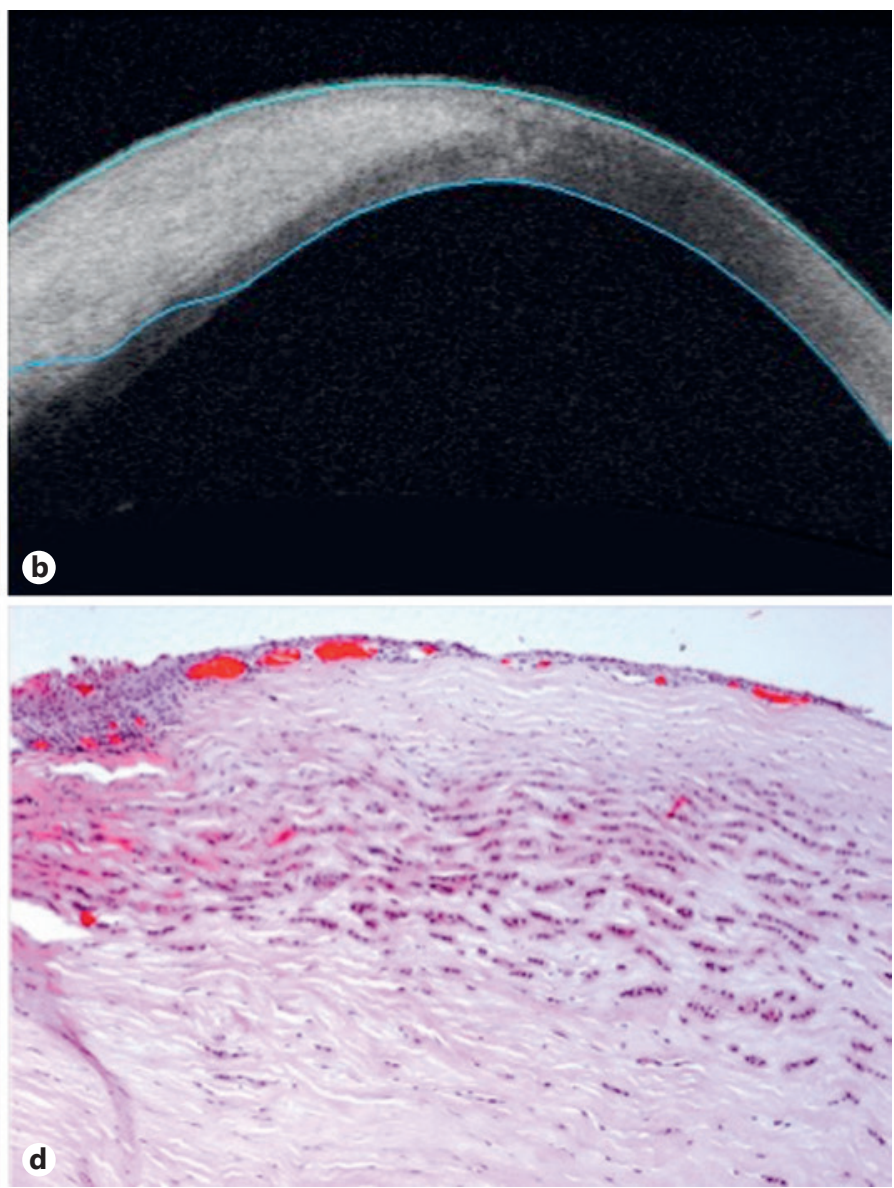

ing keratoplasty showed positive margins, an enucleation was performed. Histopathologic evaluation revealed SCC arising from the conjunctival limbal epithelium. d SCC was seen invading the deep corneal stroma extending to the opposite limbal end. HE. $\times 20$ (c). HE. $\times 20(\mathbf{d})$. managed with penetrating keratoplasty but was eventually enucleated. The final histopathologic evaluation in all cases showed SCC with invasion into the corneal stroma, 2 with the mucoepidermoid variant of SCC. The mean follow-up was 5 years (range 2-7) with no instances of local recurrence or distant metastases after definitive surgery.

\section{Discussion}

In most instances, SCC of the conjunctiva is a slowgrowing localized disease with a low potential for local spread and metastasis. Corneal stromal and intraocular invasion does occur, albeit rarely, but has been reported in $2-9 \%$ of cases. Deep corneal stromal invasion and involvement of the anterior chamber structures suggest intraocular invasion [28]. Iliff et al. [10] reported intraocular invasion in 2 of 27 patients with conjunctival SCC. Erie et al. [11] described 22 patients with SCC of whom 2 had intraocular invasion. In another report, Shields et al. [9] documented 5 patients with intraocular invasion among 150 conjunctival SCC cases. Yousef and Finger [12] reported 1 out of 36 cases of intraocular invasion. In other large OSSN case series of 389 patients (57 SCC) [29] and 288 patients (62 SCC) [7], no intraocular invasion was reported. Variants of conjunctival SCC manifest more aggressively and have an increased likelihood of exhibiting intraocular invasion, namely the mucoepidermoid $[16,30,31]$ and spindle cell variants [32-34] as well 
Table 1. Summary of patients with corneal stromal invasion of conjunctival squamous cell carcinoma

\begin{tabular}{|c|c|c|c|c|c|c|c|c|c|c|c|c|}
\hline $\begin{array}{l}\mathrm{Pa}- \\
\text { tient }\end{array}$ & $\begin{array}{l}\text { Age, } \\
\text { years }\end{array}$ & Sex & Race & $\begin{array}{l}\text { Geographic } \\
\text { location }\end{array}$ & $\begin{array}{l}\text { Location } \\
\text { of lesion }\end{array}$ & $\begin{array}{l}\text { Initial surgery } \\
\text { and pathology }\end{array}$ & $\begin{array}{l}\text { Interval } \\
\text { to corneal } \\
\text { opacity, } \\
\text { months }\end{array}$ & $\begin{array}{l}\text { Initial } \\
\text { management } \\
\text { of corneal } \\
\text { invasion }\end{array}$ & $\begin{array}{l}\text { Final } \\
\text { surgery }\end{array}$ & Final pathology & $\begin{array}{l}\text { Follow- } \\
\text { up, } \\
\text { years }\end{array}$ & $\begin{array}{l}\text { Local } \\
\text { recurrence/ } \\
\text { metastasis } \\
\text { after final } \\
\text { surgery }\end{array}$ \\
\hline 1 & 47 & $\mathrm{~F}$ & Caucasian & Australia & $\begin{array}{l}\text { Nasal } \\
\text { limbus }\end{array}$ & $\begin{array}{l}\text { Simple excision; } \\
\text { conjunctival } \\
\text { intraepithelial } \\
\text { neoplasia, grade } 1\end{array}$ & 18 & $\begin{array}{l}\text { Topical interferon } \\
\text { and retinoic acid, } \\
\text { FML, lamellar } \\
\text { keratoplasty for } \\
\text { recurrence }\end{array}$ & $\begin{array}{l}\text { Enu- } \\
\text { cleation }\end{array}$ & $\begin{array}{l}\text { SCC with deep } \\
\text { corneal stromal, } \\
\text { forniceal, and } \\
\text { scleral invasion }\end{array}$ & 5 & None \\
\hline 2 & 61 & M & Caucasian & Australia & $\begin{array}{l}\text { Nasal } \\
\text { limbus }\end{array}$ & $\begin{array}{l}\text { Simple excision; } \\
\text { pterygium with } \\
\text { focal low-grade } \\
\text { dysplasia }\end{array}$ & 12 & $\begin{array}{l}\text { Oral doxycycline, } \\
\text { topical FML, } \\
\text { topical interferon }\end{array}$ & $\begin{array}{l}\text { Enu- } \\
\text { cleation }\end{array}$ & $\begin{array}{l}\text { Mucoepidermoid } \\
\text { carcinoma with } \\
\text { deep corneal stromal, } \\
\text { scleral and intra- } \\
\text { ocular invasion }\end{array}$ & 6 & None \\
\hline 3 & 65 & M & Caucasian & USA & $\begin{array}{l}\text { Temporal } \\
\text { limbus }\end{array}$ & $\begin{array}{l}\text { Simple excision; } \\
\text { mucoepidermoid } \\
\text { carcinoma }\end{array}$ & 24 & $\begin{array}{l}\text { Lamellar } \\
\text { keratoplasty, } \\
\text { plaque } \\
\text { brachytherapy }\end{array}$ & N/A & $\begin{array}{l}\text { Mucoepidermoid } \\
\text { carcinoma with } \\
\text { deep corneal } \\
\text { stromal invasion }\end{array}$ & 7 & None \\
\hline 4 & 75 & M & Caucasian & USA & $\begin{array}{l}\text { Temporal } \\
\text { limbus }\end{array}$ & $\begin{array}{l}\text { Simple excision; } \\
\text { not submitted } \\
\text { for pathologic } \\
\text { evaluation }\end{array}$ & 12 & $\begin{array}{l}\text { Resection of } \\
\text { limbal mass, deep } \\
\text { tenonectomy, } \\
\text { resection of lateral } \\
\text { rectus, eccentric } \\
\text { penetrating } \\
\text { keratoplasty }\end{array}$ & $\begin{array}{l}\text { Enu- } \\
\text { cleation }\end{array}$ & $\begin{array}{l}\text { SCC with extensive } \\
\text { deep corneal } \\
\text { stromal invasion }\end{array}$ & 2 & None \\
\hline
\end{tabular}

F, female; M, male; FML, fluorometholone; SCC, squamous cell carcinoma; N/A, not applicable.

as patients displaying HIV positivity [35]. Rao and Font [30] reviewed 5 cases of mucoepidermoid carcinoma of the conjunctiva and found intraocular invasion in 2 cases and orbital extension in 3 cases. In our series, 2 of the 4 patients had mucoepidermoid carcinoma. In one of them, mucoepidermoid features were not readily identified on initial biopsies though focal dysplasia was noted. The tumor later on invaded intraocularly and necessitated enucleation. The other case of mucoepidermoid carcinoma was diagnosed in the initial excision of the presumed pterygium. This patient later on had tumor invasion but was limited only to the corneal stroma and did well after lamellar keratoplasty and plaque radiotherapy. This stresses the importance of histopathologic evaluation of excised presumed pterygia. In all of our cases, the initial lesions appeared clinically to be pterygia without any atypical clinical features. Unfortunately, we do not have photographs of the initial lesions because photographs were not routinely taken for ordinary pterygia. A definitive diagnosis of pterygium versus OSSN can only be made by histopathology, thus we recommend performing histopathology studies for all pterygium specimens. Variants including mucoepidermoid, spindle cell, and OSSN associated with immunosuppression or HIV coinfection should be suspected in aggressive clinical presentations, massive tumors, and recurrent manifestations $[33,36]$.
The difference in reported OSSN rates in clinically benign pterygium may be due to the wide variation in thresholds for grading squamous dysplasia between pathologists and institutions [20].

It is postulated that clinicians practicing in high UV radiation zones should always possess a higher clinical suspicion for OSSN when evaluating and managing pterygia. The contrasting incidence of OSSN between North America and African countries and Australia [4] suggests an environmental role, with UV light exposure being an important risk factor. However, immunosuppression secondary to HIV was strongly associated with an apparent increased incidence of this disease in Uganda and Malawi [37]. The mean age (62 years) of our study's patients represented an older demographic, aligning with the established dogma of older age being one of the risk factors for OSSN, and underscores the importance of having a higher clinical suspicion for OSSN in this patient demographic.

Conjunctival SCC commonly extends to the surface epithelium of the cornea but rarely invades into the deep corneal stroma. It has been hypothesized that invasion of the corneal stroma is facilitated by prior surgical intervention, creating a point of entry for invading tumor cells [38]. This phenomenon's mechanism is thought to be associated with the disruption of the Bowman layer, which 
is thought to serve as a barrier for tumor invasion [7]. Patients with a history of OSSN who undergo intraocular surgery such as cataract surgery are at increased risk of neoplastic intraocular extension [39]. The only surgical procedure our patients reportedly had was the initial simple excision of the presumed pterygium; they did not have any subsequent intraocular surgery prior to the development of corneal invasion. Two of our 4 cases were of the mucoepidermoid variant, which explains the aggressive nature of their clinical course. For the other 2 cases, however, we suspect that a violation of the Bowman layer during the initial excision allowed for intracorneal stromal invasion. Intraocular involvement of conjunctival SCC occurring through emissary vessels near the area of the limbus has also been reported [15].

The ability of conjunctival SCC to exhibit intracorneal and intraocular invasion highlights the need for complete excision of the primary tumor at the time of initial surgery. While the gold standard surgical management of pterygium is by excision with autoconjunctival, reconstructive grafting [40], the adjunctive use of mitomycin C is widespread, yet controversial $[40,41]$. Where mitomycin C is used in pterygium surgery, it would potentially be helpful in cases of undetected OSSN, although the risk of long-term complications has resulted in alternative, efficacious treatments such as topical interferon alfa-2b [27]. In one study [23], cases that were clinically suspicious for OSSN with pterygia were treated with wide surgical margins and cryotherapy and no recurrences were reported. In the same study, 6 out of 20 patients found to have unexpected OSSN with pterygia after simple excision were treated with adjuvant topical interferon. The recurrence rate was $24 \%$ at 2 years of follow-up with no reports of corneal invasion. Complete clinical resolution of OSSN lesions was achieved in 87 of 89 eyes $(97.75 \%)$ with a combination of topical interferon alfa- $2 \mathrm{~b}$ and retinoic acid, with faster resolution time compared to interferon alone [27].

The clinical diagnosis of intracorneal and intraocular invasion of conjunctival SCC can be challenging. Our cases demonstrate the variation in clinical presentations of intracorneal and intraocular invasive SCC. Case 1 presented with a recurrent limbal lesion, with accompanying corneal opacity and photophobia that initially regressed with topical interferon treatment but nevertheless recurred. Case 2 presented with prominent inflammation for which topical steroids were administered before an elevated limbal nodule developed, prompting subsequent excision. In case 3, the disease manifested only as a corneal stromal opacity/corneal haze without an apparent

Invasive Corneal Squamous Cell Carcinoma epithelial abnormality and did well after keratoplasty. Case 4 had a nonhealing corneal defect that later evolved to an extensive corneal opacity spanning the entire cornea, demonstrated by anterior segment OCT. Imaging techniques such as anterior segment OCT [42], high-frequency ultrasound biomicroscopy [28], and confocal microscopy [43] are utilized for in vivo detection of corneal stromal invasion or intraocular extension (angle blunting, iris disinsertion, or uveal thickening) [28]. Patients with intraocular invasion may also present clinically with signs and symptoms of uveitis (tumor cells in the anterior chamber and intraocular inflammation suggesting iridocyclitis) and/or secondary glaucoma (SCC invading the trabecular meshwork) [9].

Globe-sparing deep lamellar keratoplasty and sclerokeratoplasty are warranted for tumors with deep corneal invasion. One case report highlighted deep corneal invasion without intraocular involvement, where surgery involved lamellar sclerectomy, and penetrating sclerokeratoplasty with no recurrence 12 months postoperatively [13]. Another report described a case of deep corneal stromal involvement by conjunctival spindle cell carcinoma managed with full-thickness eye wall resection and scleral graft [32]. Lamello-lamellar sclerokeratoplasty was performed for a massive conjunctival SCC with corneal involvement with no recurrence after 3 years of follow-up [38]. Plaque brachytherapy has been shown to be effective for the management of ocular surface malignancies with corneoscleral invasion. Six patients with recurrent SCC and 5 patients with conjunctival melanoma, all with deep corneal and scleral invasion, were treated with surgical excision followed by plaque brachytherapy with no local recurrences and no distant metastasis after a mean follow-up of 23 months [44]. Local tumor control was achieved by plaque brachytherapy for residual scleral invasive SCC [45]. For intraocular involvement, modified enucleation (standard enucleation with excision of affected conjunctival tissue) is the preferred treatment option [9].

In summary, we have reviewed 4 patients with corneal stromal invasion by conjunctival SCC after excision of presumed pterygia. Undetected conjunctival epithelial dysplasia may give rise to potentially vision- and eyethreatening invasive corneal SCC.

This series emphasizes the importance of careful histopathologic evaluation of all pterygium specimens for evidence of OSSN and for pathologists to be cognizant of variants of SCC that are associated with increased risk of intraocular invasion. Intracorneal and intraocular invasion of conjunctival SCC is rare and diagnostically chal- 
lenging, and clinical suspicion should be maintained in cases of recurrent conjunctival squamous neoplasia, particularly if there is associated corneal stromal opacity. The management depends on the extent of tumor involvement. Limited corneal invasion can be successfully managed with keratoplasty with or without plaque brachytherapy. Extensive deep corneal involvement and intraocular invasion warrant enucleation. Further recurrence and metastasis appear to be uncommon.

\section{Statement of Ethics}

The authors have no ethical conflicts to disclose.

\section{Disclosure Statement}

The authors have no conflicts of interest to disclose.

\section{References}

1 Chui J, Di Girolamo N, Wakefield D, Coroneo MT: The pathogenesis of pterygium: current concepts and their therapeutic implications. Ocul Surf 2008;6:24-43.

2 Chui J, Coroneo MT: Pterygium pathogenesis, actinic damage, and recurrence; in Hovanesion JA (ed): Pterygium: Techniques and Technologies for Surgical Success. Thorofare, SLACK Incorporated, 2012, pp 1-26.

3 Coroneo M: Ultraviolet radiation and the anterior eye. Eye Contact Lens 2011;37:214224.

4 Lee GA, Hirst LW: Incidence of ocular surface epithelial dysplasia in metropolitan Brisbane. A 10-year survey. Arch Ophthalmol 1992; 110:525-527.

5 McClellan AJ, McClellan AL, Pezon CF, Karp CL, Feuer W, Galor A: Epidemiology of ocular surface squamous neoplasia in a veterans affairs population. Cornea 2013;32:13541358.

6 Gichuhi S, Sagoo MS, Weiss HA, Burton MJ: Epidemiology of ocular surface squamous neoplasia in Africa. Trop Med Int Health 2013;18:1424-1443.

7 Lee GA, Hirst LW: Retrospective study of ocular surface squamous neoplasia. Aust NZ J Ophthalmol 1997;25:269-276.

8 Grossniklaus HE, Green WR, Luckenbach M, Chan CC: Conjunctival lesions in adults. A clinical and histopathologic review. Cornea 1987;6:78-116.

9 Shields JA, Shields CL, Gunduz K, Eagle RC Jr: The 1998 Pan American Lecture. Intraocular invasion of conjunctival squamous cell carcinoma in five patients. Ophthal Plast Reconstr Surg 1999;15:153-160.

10 Iliff WJ, Marback R, Green WR: Invasive squamous cell carcinoma of the conjunctiva. Arch Ophthalmol 1975;93:119-122.

11 Erie JC, Campbell RJ, Liesegang TJ: Conjunctival and corneal intraepithelial and invasive neoplasia. Ophthalmology 1986;93:176-183.

12 Yousef YA, Finger PT: Squamous carcinoma and dysplasia of the conjunctiva and cornea: an analysis of 101 cases. Ophthalmology 2012; 119:233-240.
13 Roy A, Rath S, Das S, Vemuganti GK, Parulkar G: Penetrating sclerokeratoplasty in massive recurrent invasive squamous cell carcinoma. Ophthal Plast Reconstr Surg 2011; 27:e39-e40.

14 Rootman DB, McGowan HD, Yucel YH, Pavlin CJ, Simpson ER: Intraocular extension of conjunctival invasive squamous cell carcinoma after pterygium surgery and cataract extraction. Eye Contact Lens 2012;38:133-136.

15 Zhang Z, Li B, Shi J, Xu X, Li L, Gao F: Intraocular extension of conjunctival squamous cell carcinoma. Ophthalmologica 2007;221: 200-203.

16 Brownstein S: Mucoepidermoid carcinoma of the conjunctiva with intraocular invasion. Ophthalmology 1981;88:1226-1230.

17 Ali MJ, Pujari A, Dave TV, Kaliki S, Naik MN Clinicopathological profile of orbital exenteration: 14 years of experience from a tertiary eye care center in South India. Int Ophthalmol 2016;36:253-258.

18 Woods M, Chow S, Heng B, Glenn W, Whitaker N, Waring D, Iwasenko J, Rawlinson W, Coroneo MT, Wakefield D, Di Girolamo N: Detecting human papillomavirus in ocular surface diseases. Invest Ophthalmol Vis Sci 2013;54:8069-8078.

19 Chui J, Coroneo MT, Tat LT, Crouch R, Wakefield D, Di Girolamo N: Ophthalmic pterygium: a stem cell disorder with premalignant features. Am J Pathol 2011;178:817827.

20 Segev F, Mimouni M, Tessler G, Hilely A, Ofir S, Kidron D, Bahar I: A 10-year survey: prevalence of ocular surface squamous neoplasia in clinically benign pterygium specimens. Curr Eye Res 2015;40:1284-1287.

21 Yeung SN, Kim P, Lichtinger A, Amiran MD, Cote E, Teitel S, Slomovic AR: Incidence of ocular surface squamous neoplasia in pterygium specimens: an 8-year survey. Br J Ophthalmol 2011;95:592.

22 Hirst LW, Axelsen RA, Schwab I: Pterygium and associated ocular surface squamous neoplasia. Arch Ophthalmol 2009;127:31-32.
23 Oellers P, Karp CL, Sheth A, Kao AA, Abdelaziz A, Matthews, JL, Dubovy SR, Galor A: Prevalence, treatment, and outcomes of coexistent ocular surface squamous neoplasia and pterygium. Ophthalmology 2013;120:445450.

24 Shields JA, Shields CL, De Potter P: Surgical management of conjunctival tumors. The 1994 Lynn B. McMahan Lecture. Arch Ophthalmol 1997;115:808-815.

25 Tabin G, Levin S, Snibson G, Loughnan M, Taylor H: Late recurrences and the necessity for long-term follow-up in corneal and conjunctival intraepithelial neoplasia. Ophthalmology 1997;104:485-492.

26 Schechter BA, Koreishi AF, Karp CL, Feuer $\mathrm{W}$ : Long-term follow-up of conjunctival and corneal intraepithelial neoplasia treated with topical interferon alfa-2b. Ophthalmology 2008;115:1291-1296.

27 Krilis M, Tsang H, Coroneo M: Treatment of conjunctival and corneal epithelial neoplasia with retinoic acid and topical interferon alfa2b: long-term follow-up. Ophthalmology 2012;119:1969-1973.

28 Finger PT, Tran HV, Turbin RE, Perry HD, Abramson DH, Chin K, Della Rocca R, Ritch R: High-frequency ultrasonographic evaluation of conjunctival intraepithelial neoplasia and squamous cell carcinoma. Arch Ophthalmol 2003;121:168-172.

29 Galor A, Karp CL, Oellers P, Kao AA, Abdelaziz A, Feuer W, Dubovy SR: Predictors of ocular surface squamous neoplasia recurrence after excisional surgery. Ophthalmology 2012;119:1974-1981.

30 Rao NA, Font RL: Mucoepidermoid carcinoma of the conjunctiva: a clinicopathologic study of five cases. Cancer 1976;38:1699-1709.

31 Robinson JW, Brownstein S, Jordan DR, Hodge WG: Conjunctival mucoepidermoid carcinoma in a patient with ocular cicatricial pemphigoid and a review of the literature. Surv Ophthalmol 2006;51:513-519.

32 Shields JA, Eagle RC, Marr BP, Shields CL, Grossniklaus HE, Stulting RD: Invasive spindle cell carcinoma of the conjunctiva managed by full-thickness eye wall resection. Cornea 2007;26:1014-1016. 
33 Mittal R, Rath S, Vemuganti GK: Ocular surface squamous neoplasia - review of etiopathogenesis and an update on clinico-pathological diagnosis. Saudi J Ophthalmol 2013; 27:177-186.

34 Alkatan HM, Al-Motlak MA, Al-Shedoukhy AA: Metastatic squamous spindle cell carcinoma of the conjunctiva. Saudi J Ophthalmol 2010;24:155-158.

35 Kamal S, Kaliki S, Mishra DK, Batra J, Naik MN: Ocular surface squamous neoplasia in 200 patients: a case-control study of immunosuppression resulting from human immunodeficiency virus versus immunocompetency. Ophthalmology 2015;122:1688-1694.

36 Shields CL, Ramasubramanian A, Mellen PL, Shields JA: Conjunctival squamous cell carcinoma arising in immunosuppressed patients (organ transplant, human immunodeficiency virus infection). Ophthalmology 2011;118: 2133-2137.
37 Waddell KM, Lewallen S, Lucas SB, AtenyiAgaba C, Herrington CS, Liomba G: Carcinoma of the conjunctiva and HIV infection in Uganda and Malawi. Br J Ophthalmol 1996; 80:503-508.

38 Panda A, Sharma N, Sen S: Massive corneal and conjunctival squamous cell carcinoma. Ophthalmic Surg Lasers 2000;31:71-72.

39 Murillo JC, Galor A, Wu MC, Kye NK, Wong J, Ahmed IO, Joag M, Shalabi N, Lahners W, Dubovy S, Karp CL: Intracorneal and intraocular invasion of ocular surface squamous neoplasia after intraocular surgery: report of two cases and review of the literature. Ocul Oncol Pathol 2017;3:66-72.

40 Coroneo MT, Chui JJY: Pterygium; in Holland EJ, Mannis MJ, Lee WB (eds): Ocular Surface Disease: Cornea, Conjunctiva and Tear Film. Philadelphia, Saunders Elsevier, 2013, pp 125-144.

41 Hirst LW: Mitomycin C in the treatment of pterygium. Clin Exp Ophthalmol 2006;34: 197-198.
42 Thomas BJ, Galor A, Nanji AA, El Sayyad F, Wang J, Dubovy SR, Joag MG, Karp CL: Ultra high-resolution anterior segment optical coherence tomography in the diagnosis and management of ocular surface squamous neoplasia. Ocul Surf 2014;12:46-58.

43 Balestrazzi A, Martone G, Pichierri P, Tosi GM, Caporossi A: Corneal invasion of ocular surface squamous neoplasia after clear corneal phacoemulsification: in vivo confocal microscopy analysis. J Cataract Refract Surg 2008;34:1038-1043.

44 Walsh-Conway N, Conway RM: Plaque brachytherapy for the management of ocular surface malignancies with corneoscleral invasion. Clin Exp Ophthalmol 2009;37:577-583.

45 Arepalli S, Kaliki S, Shields CL, Emrich J, Komarnicky L, Shields JA: Plaque radiotherapy in the management of scleral-invasive conjunctival squamous cell carcinoma: an analysis of 15 eyes. JAMA Ophthalmol 2014;132: 691-696. 